\title{
IMPROVING SPEAKING PERFORMANCE THROUGH PECHA KUCHA PRESENTATION METHOD
}

\author{
Sefvirda Arniatika \\ University of Lampung, Lampung \\ E-mail: Sefvirdaa@gmail.com
}

\begin{abstract}
The objective of this research is to show the improvement of the students' speaking performance using Pecha Kucha presentation method among the tenth graders of SMA Muhammadiyah East Lampung. The research method used in this research is a Classroom Action Research (CAR) which is used to solve the students' problem in speaking performance. The subjects of this research are X MIA students of SMA Muhammadiyah Pekalongan East Lampung in the academic year of 2017/2018. The research instruments used to collect the data in this research are test, observation and documentation. The result of this research shows that the implementation of Pecha Kucha presentation method is successful since the criteria of success are achieved. The first criterion is $70 \%$ of the students could pass the target score $\geq 70$ based on the KKM. The finding shows that $77.78 \%$ of the students had already achieved the target score. Besides, the second criterion is the students who became more active in the learning process. The result of observation shows that by using Pecha Kucha presentation method, most of the students are involved actively in the learning process.
\end{abstract}

Keywords: Speaking, Peach Kucha, Presentation Method.

\section{INTRODUCTION}

English is spreading around the world not only as the role of the international language but also as the acknowledgement of English as first, second and foreign language. Floris (2014:215) states that English is truly regarded as an international language. In many countries, the most students learned and spoken by using English. In the development of English today, most of countries are adopted English as the official language or even just the foreign language. Particularly, in Indonesia, English is considered as the primary foreign language which is given more importance than any of the other foreign languages being taught. This implies that English cannot be separated from both the education system of Indonesia and Indonesian students' daily activities. As the role of the tool in the students' daily life, English seems to be the basis on how much the students as the language learner can use and improve their spoken language. In addition, that is no doubt to state that speaking is the hardest skill ever among the others to be mastered.

Furthermore, speaking as the hardest skill is one of the productive skills that functions to express something from the speaker to the listener in the way of spoken language. O'Malley and Pierce (1996:59) state that speaking is negotiating intended meanings and adjusting one's speech to produce the desired effect on the listener. It means that oral communication involves the negotiation of meaning between two or more 
persons that is always related to the context in which it occurs, anticipating the listener's response and possible misunderstandings, clarifying one's own and the other's intention.

Moreover, there is Rickheit and Strohner (2008:207) who claimed that speaking is speech or utterances with the purpose of having intention to be recognized by the speaker and the receiver processes the statements in order to recognize their intentions. Moreover, Brown and Yule (1999:14) stated that speaking is depending on the complexity of the information to be communicated; however, the speaker sometimes finds it difficult to clarify what they want to say. In addition, Rebecca (2006:144) stated that speaking is the first mode in which children acquire language which is the part of daily involvement of most people with language activities, and it is the prime motor of language change. From those definitions above, the researcher concludes that the definition of speaking is an interactive process of constructing meaning by involving non-verbal language to express and help the communication effectively.

Many of the students are complaining about their incompetence in speaking. The main reason under investigation is because English is not the mother tongue of Indonesian students so that the students are not familiar with English to communicate. On the other hand, students are difficult to speak English because the methods of learning are unsuitable and ineffective. In short, it is obviously that students are low in motivating themselves to perform speaking. Regarding to Brown (2000:30), performance is the overtly observable and concrete manifestation or realization of competence. This term describes that performance can be observed by actual doing about something. Bad or good someone's competence can be measured by his or her real performance.

Whereas, Ellis (2003:13) claimed that performance consists of the use of grammar in the comprehension and production of language. This theory sees performance based on the content of that performance itself, such as grammar and language. In addition, there is Chomsky (1996:13) who stated that performance is related to the term of competence and defined as the specific application of particular language in production and understanding of utterances. Thus, speaking performance is the act of conveying messages from the speaker to the listener through words, utterance, and sentences where their performance in speaking will automatically show their good or bad competence either.

As the researcher found in the location of the study at SMA Muhammadiyah Pekalongan East Lampung among the tenth graders, there are many specific problems faced by the students in their speaking such as; the students are having so much time to think before speaking and sometimes they have no idea to say. These cases can be affected by some factors among others; the students' interest in speaking, the material, the media, and the unsuitable method in English teaching. Beside of that, the traditional teaching is also giving the contribution in their difficulty because they cannot develop their own way to express themselves.

In the relation to the data above, the researcher find out an alternative way to create a suitable and an effective method in order to assist the students and improve their speaking performance. One of the alternative ways is by applying the method of Pecha Kucha presentation. Pecha Kucha is to keep 
presentations concise, the interest level up, and to have many presenters share their ideas within the course of one meeting (Herchmer, 2012: 55). Furthermore, Pecha Kucha is a method of presentation which is designed by using 20 slides shown for 20 seconds

(Reynolds, 2012:41). Moreover, Keith and Lundberg (21014:247) stated that Pecha Kucha is a presentation format which consists of 20 slides shown for 20 seconds each; 400 seconds $=6$ minutes and 40 seconds for a speech. The slides are obviously designed to advance automatically, so the speaker has no choice but to be concise and keep with the audience. Because speaking seems to be the most important skill, so it must be paid more attention to have a better way in teaching. This Pecha Kucha presentation method is a format of presentation by using slides in the way of 20x20 means 20 slides in 20 seconds per slide. This method gives the students an opportunity to practice their speaking so that they can improve their own performance.

Based on the statements above, the researcher take a study under the title: "Improving Speaking Performance through Pecha Kucha Presentation Method among the Tenth Graders of SMA Muhammadiyah Pekalongan East Lampung”.

\section{METHOD}

The researcher conducted the research among the tenth graders of SMA Muhammadiyah Pekalongan East Lampung, which is located in Jalan Raya Pekalongan, Pekalongan, East Lampung. Besides, the time to conduct the research would be in the effective time of teaching and learning at school.

The subject of the research was the students of $\mathrm{X}$ (Tenth) grade of SMA Muhammadiyah Pekalongan East Lampung. From 2 classes of the tenth grade, X MIA was choosen as the subject of the research. This class was choosen because it was a worse class which had many more problems in speaking rather than another class. Hence, their speaking performance needed to be improved.

The researcher applied the Classroom Action Research. According to Ary et.al., (2010:514) action research is a planned, systematic, and cyclical approach to understanding the process of learning and to analyzing the work of educational places.

In this research, the researcher adopted the procedure of Classroom Action Research from Kemmis and Mc Taggart, they are: preliminary observation (reconnaissance), planning, implementing, observing and reflecting.

\section{Reconnaissance}

In this step of research procedure, the researcher directly observed the process of teaching and learning in the classroom, identified some problems of the research location and collected the pretest score of the students' speaking performance.

\section{Planning}

In this step, the researcher conducted the action research among $\mathrm{X}$ MIA graders of SMA Muhammadiyah Pekalongan East Lampung in several cycles. The researcher discussed with the English teacher or collaborator to determine the actions to solve the existing problems. Besides, this step also covered socializing the research program, designing lesson plan and preparing the indicator of succes.

\section{Implementing}

In this step, the researcher conducted the teaching by using Pecha Kucha presentation method. Therefore, the researcher played the 
role as the teacher and worked collaboratively with the collaborator (English Teacher). In this case, the collaborator also played as the observer. When the researcher as the teacher applied Pecha Kucha presentation method in teaching speaking, the English teacher as the collaborator observed the process of the teaching and learning with the observation sheet which is prepared by the researcher. At last, the researcher gave a post-test to the students by using oral test.

\section{Observing}

In this step, the researcher collected the data and valuable information which is gathered by the observer about the students' responses, participation, achievement and everything found during the teaching and learning process.

\section{Reflecting}

In this step, the researcher analyzed the data and made the reflection of the actions. If the result of the actions did not show the improvement of the students' speaking performance as stated in the indicator of success, the researcher would do the next cycle.

\section{Data Collecting Technique}

The term of data collecting technique refers to the way on how the data is gathered in order to ensure the acquisition of relevant and valid information (Tomal, 2003:25). In completing the data, the researcher used qualitative data and quantitative data. In order to gain the qualitative data, the researcher used observation and documentation. Meanwhile, in gaining the quantitative data, the researcher used pre-test and post test.

\section{Observation}

The researcher used the observation guidelines as the instrument in collecting the data. In addition, the researcher made the observation checklist based on the guidelines about teacher's performance in teaching speaking, students' learning activities and students' speaking performance by using Pecha Kucha presentation.

\section{Documentation}

The researcher used the documentation guidelines as the instrument in collecting the data. Related to the guidelines, the researcher made the documentation items about the condition of the teachers and data is gathered in order to ensure the acquisition of relevant and valid information. In completing the data, the researcher used qualitative data and quantitative data.

\section{Test}

The test was conducted to assess the students' speaking performance both individually and group in the form of oral test.

\section{RESULTS AND DISCUSSION \\ Reconnaissance}

In order to find the problems related to the teaching and learning process of class X MIA in SMA Muhammadiyah Pekalongan East Lampung, the researcher conducted some sequences of the observation. The observation was conducted on Friday, September 29th 2017. Based on the observation, it was known that the process of teaching and learning in the classroom is ineffective and not conducive. It was described when the teacher delivered the material, there were no students who made a good response actively. The students tended 
to keep silent all the time unless the teacher asked them to speak up.

After observing the classroom activity, the researcher collected the pretest score of students' speaking performance. The pretest was conducted on Friday, October 6th 2017 by measuring the students' speaking performance. The students' score of pretest was collected by asking the students to perform in front of the class in order to do a brief introduction. They were asked to tell about themselves orally.

Table 1

Students' Mark of Pretest of Speaking Performance Pretest

\begin{tabular}{|c|c|c|c|}
\hline No & Mark & Frequency & Category \\
\hline 1 & $\geq 70$ & 4 & Passed \\
\hline 2 & $<70$ & 14 & Failed \\
\hline \multicolumn{2}{|c|}{ Total Students } & 18 & \\
\hline
\end{tabular}

From the data above, the researcher concluded that the students' score of speaking performance was poor. Besides, this number implies that; the students spoke less fluently and had few long breaks; the students' speech was not comprehensible and there were some mispronunciations too; the students used limited vocabularies and inappropriately; the students had many grammatical mistakes. The researcher had identified the field problems found in teaching and learning process as follows:

a. The students were not confident to speak English.

b. The students did not speak English fluently.

c. The students had difficulties in using grammar.

d. The students found difficulties in pronouncing some English words.

e. The students were lack of vocabularies.

f. The students often used Bahasa Indonesia to speak, especially to answer the teacher's questions. g. The students depended on the materials given by the teacher and did not initiate to suffice their needs of materials.

h. The students had fewer practices of speaking.

i. The students were not totally giving more attention to their teacher.

j. The method used by the teacher did not engage to the students to speak up.

$\mathrm{k}$. The teacher did not develop the media to teach speaking effectively.

\section{Cycle I}

Cycle I consists of planning, implementing, observing and reflecting. Here is the details explanation of each step in Cycle I.

\section{Planning}

According to the result of the pretest above, the researcher has identified and found the problems after taking the students' pretest score. Therefore, the researcher and collaborator prepared several things related to teaching and learning process such as the English subject lesson plan, the material, media, observation sheet that contains about list of students' names and activity, and evaluation for the next meeting.

\section{Implementing}

In this step, the researcher conducted the implementation of the treatment in the next meeting. The researcher conducted the treatment on Friday, October 13rd, 2017. In this meeting, the role of the researcher was as an English teacher and Mrs. Atmaliyati, S.S. was as a collaborator. The researcher started the meeting by praying, greeting, checking attendance list and asking the condition of the students. Afterwards, the researcher gave the material about recount text.

At the beginning of teaching and learning process, the researcher asked to the 
students about recount text. Some of the students did not know at all about recount text. Secondly, the researcher explained about definition, generic structure, social function and language feature of recount text.

Afterwards, the researcher explained about the concept of Pecha Kucha presentation method. The researcher divided the students into four groups that contained 4-5 students. The researcher gave the example of Pecha Kucha presentation in slides using power point. Then, each group were asked to organize a presentation about their personal experience in 20 slides. Each group was given a chance to discuss and provided some pictures to be showed in their slides as the content of the presentation. As long as the students studied in group, the researcher went around in the class and helped the students to compose a good presentation. In another hand, the students must be pointed out the picture only and took a note to be presented orally. Then, the students should practice their works in front of the class. The researcher guided all students of each group to be actively in their works. Then each group presented the result of discussion. Afterwards, the researcher gave some additions of their work and performance.

In the end of meeting, the researcher gave feedback to the students of the learning process. The researcher gave motivation and informed to the students about the activities in the next meeting. Then, the researcher closed the material by praying together.

After did a treatment, the researcher gave post-test to the students. The post-test was conducted on Friday, October 20th, 2017. The post-test was done to know the improvement of the students' speaking performance after giving treatment. The researcher asked the students to do a Pecha
Kucha presentation about their personal experience. The result of post-test in cycle I could be seen on the table, as follows:

Table 2

Students' Mark of Post-test I of Speaking Performance

\begin{tabular}{cccc}
\hline No & Mark & Frequency & Category \\
\hline 1 & $\geq 70$ & 6 & Passed \\
2 & $<70$ & 12 & Failed \\
Total & Students & $\mathbf{1 8}$ & \\
\hline
\end{tabular}

From the table 2, it could be analyzed that the students' average score was 64,11 . The highest score was 76 and the lowest score was 50. Based on the minimum mastery criteria $(\mathrm{KKM})$, there were 6 students that had passed on post-test I or got score $\geq 70$. It means that in cycle I, the students' achievement was improved enough, but it was not successful yet.

\section{Observing}

In this step, the researcher observed the students activities during the learning process. Besides, there was a collaborator who also observed the teacher's performance of the researcher during teaching the students using the method of Pecha Kucha presentation.

In the learning process, there were five indicators used and mentioned to know the students' learning activities. Every student who was active in learning process was given a thick in the observation sheet. Then, the students were not active in learning process, let the observation sheet empty. It can be seen on the appendix. The indicators of the students' activities were:

a. The students attended the class of English subject.

b. The students paid attention while in the process of teaching and learning.

c. The students worked in group actively. 
d. The students were confident to present their presentation.

e. The students had a good understanding in their own material.

The result of the students' learning activities could be seen as follows:

Table 3

The Students' Activities in Cycle I

\begin{tabular}{|c|c|c|c|}
\hline $\begin{array}{l}\mathbf{N} \\
\mathbf{0}\end{array}$ & $\begin{array}{l}\text { Students } \\
\text { Activities }\end{array}$ & Frequency & $\overline{\text { Percentage }}$ \\
\hline 1 & $\begin{array}{l}\text { The students } \\
\text { attended the class } \\
\text { of English subject. }\end{array}$ & 18 & $100 \%$ \\
\hline 2 & $\begin{array}{l}\text { The students paid } \\
\text { attention while in } \\
\text { the process of } \\
\text { teaching and } \\
\text { learning. }\end{array}$ & 14 & $77.78 \%$ \\
\hline 3 & $\begin{array}{l}\text { The students } \\
\text { worked in group } \\
\text { actively. }\end{array}$ & 10 & $55.55 \%$ \\
\hline 4 & $\begin{array}{l}\text { The students were } \\
\text { confident to } \\
\text { present their } \\
\text { presentation. }\end{array}$ & 5 & $27.78 \%$ \\
\hline 5 & $\begin{array}{l}\text { The students had a } \\
\text { good } \\
\text { understanding in } \\
\text { their own } \\
\text { material. }\end{array}$ & 6 & $33.33 \%$ \\
\hline \multicolumn{2}{|c|}{ Total students } & 18 & \\
\hline
\end{tabular}

The table showed that the presence of the students in attending English subject class was 18 students (100\%). Besides, there were 14 students $(77.78 \%)$ who gave attention to the teacher's explanation, 10 students $(55.55 \%)$ who active in group, 5 students $(27.78 \%)$ who were confident to deliver their presentation, and 6 students $(33.33 \%)$ who understood the materials.

Based on the result above, it could be inferred that the learning process of cycle I was not successful yet because only two activities, they were the students' presence and the students attention, that got the percentage of $\geq 70 \%$ and the others got $<70 \%$.

\section{Reflecting}

In this step, the researcher concluded that cycle I did not run well because most of students did not achieve the minimum mastery criteria (KKM). It could be seen from the result of pretest and post-test I score.

From the result of observation in cycle I, there were some problems that found, as follows:

a. There were some students that shown unenthusiastic to the teacher's explanation.

b. Some students did not active in group.

c. Some students had many more anxiety and less of confidence.

d. Some students did not understand the material.

Based on the result of reflection in cycle I, there were some problems to be revised in cycle II, such as:

a. The teacher gave more motivation to the students in order to encourage them in studying harder and made the learning process more interesting, communicative and attractive.

b. The teacher gave more detail explanation and questions after explaining the materials to control the students' comprehension.

c. The teacher guided the students who they were not active yet in a group discussion.

In this research, pretest and post-test I had done individually. It was aimed to know the students' speaking performance before and after the treatment. From the result of pretest and post-test $\mathrm{I}$, it can be analyzed that there was an improvement from the students' result score. It could be seen from the average score in pretest 61,89 and post-test I 64,11. Although there was an improvement of the students' achievement, cycle I was not successful yet because only 6 students 
(33.33\%) who passed in post-test I. It can be concluded that cycle I was not successful yet because the indicator of success was not reached yet and the researcher had to revise the teaching and learning process in the next cycle. Therefore, this research would be continued in the next cycle.

\section{Cycle II}

The cycle II was similar with cycle I. It was divided into planning, implementing, observing, and reflecting. It would be explained more as follows:

\section{Planning}

Based on the observation and reflection in cycle I, it showed that cycle I was not successful yet. Therefore, the researcher and the collaborator tried to revise the several problems that appeared in cycle I and arranged the planning for continuing in cycle II. The researcher prepared the lesson plan, material, media, and post-test II.

\section{Implementing}

The description of the teaching and learning process of cycle II was not different from the previous cycle. In each treatment, the researcher tried to make the students be more active. The implementation of this step was conducted in two meetings, namely: treatment and post-test II.

The treatment in cycle II was conducted on Friday, October 27th, 2017. It was started by greeting and asking the students condition. The researcher as a teacher explained the material about procedure text. The teacher asked to the students to mention about definition of procedure text, generic structure, social function, and language features. Moreover, the teacher divided the students into 4 groups as in previous cycle. In groups, the students discussed the text about "How to make food and beverage". Then, the teacher asked them to discuss about the pictures of the procedure text. The teacher guided the students to be active in group and after all the groups finished the discussion, the teacher asked each group to present their work.

In the end of meeting, the teacher closed the meeting and gave motivation to the students to study hard and tries to speak up more in order to get good scores especially in English subject.

After giving the treatment in cycle II, the researcher conducted post-test II on Friday, November 3rd, 2017. The test was asked the students to present their presentation in front of the class by using the method of Pecha Kucha presentation. It was the same type as the first cycle but in the different kind of text. The result of post-test II could be seen on the table below:

Table 4

Students' Mark of Post-test II of Speaking Performance

\begin{tabular}{cccc}
\hline No & Mark & Frequency & Category \\
\hline 1 & $\geq 70$ & 14 & Passed \\
2 & $<70$ & 4 & Failed \\
Total Students & & $\mathbf{1 8}$ & \\
\hline
\end{tabular}

Based on the table above, it could be seen that the students' average score in post-test II was 69,67 . The highest score was 76 and the lowest score was 58. According to the minimum mastery criteria (KKM), $77.78 \%$ students had passed the test. Most of the students could improve their speaking performance. It means that cycle II was successful.

\section{Observing}

In this step, the role of the researcher and the collaborator was same as the previous step in the cycle I that was to observe the students' learning activities and teacher's performance. 
There were also five indicators used to know the students' activities.

Based on the result of the observation sheet in cycle II, the researcher indicated that learning process in cycle II was successful. The result score of students' learning activities observation, as follows:

Table 5

The Students' Activities in Cycle II

\begin{tabular}{|c|c|c|c|}
\hline $\begin{array}{l}\mathbf{N} \\
\mathbf{0}\end{array}$ & Students Activities & Frequency & Percentage \\
\hline 1 & $\begin{array}{l}\text { The students attended } \\
\text { the class of English } \\
\text { subject. }\end{array}$ & 18 & $100 \%$ \\
\hline 2 & $\begin{array}{l}\text { The students paid } \\
\text { attention while in the } \\
\text { process of teaching } \\
\text { and learning. }\end{array}$ & 16 & $88.89 \%$ \\
\hline 3 & $\begin{array}{l}\text { The students worked } \\
\text { in group actively. }\end{array}$ & 15 & $83.33 \%$ \\
\hline 4 & $\begin{array}{l}\text { The students were } \\
\text { confident to present } \\
\text { their presentation. }\end{array}$ & 14 & $77.78 \%$ \\
\hline 5 & $\begin{array}{l}\text { The students had a } \\
\text { good understanding in } \\
\text { their own material. } \\
\text { Total students }\end{array}$ & 13 & $72.22 \%$ \\
\hline
\end{tabular}

The table above showed that the students' activity in cycle II was improved. The students' activities that had high percentage were students' presence in English subject class (100\%) and the secondhigh percentage was students' attention (88.89\%), then the third was students' who active in group (83.33\%). The fourth-high percentage was the students' confidence $(77.78 \%)$ and the last was the students' understanding (72.22\%). Based on the result above, the researcher indicated that learning process in cycle II was successful because all indicators of the students' learning activities got the percentage of $\geq 70 \%$.

Based on the result of the research in cycle II, it could be inferred that cycle II was successful. There was $>70 \%$ of students who passed the post-test. It means that the students' speaking performance had improved. From the result above, the researcher concluded that this research was successful and would not be continued to the next cycle.

\section{INTERPRETATION}

\section{Cycle I}

In the first step of Cycle I, the researcher discussed with the collaborator, Mrs. Atmaliyati, S.S. to prepare some kinds of teaching designs. Then, in the implementation stage, the researcher gave the treatment to the students. The treatment was conducted by teaching the students using Pecha Kucha presentation method. Furthermore, the researcher gave the posttest in the next meeting and the post-test was named post-test I.

Afterwards, by analyzing the result of post-test I, the researcher concluded that there were 6 students $(33.33 \%)$ students who passed the post-test I. The lowest score was 50 , the highest score was 76, and the average score was 64,11 .

From the result of the students' score in pretest and post-test I, there was an improvement from the students' result score. It could be seen from the average score in pretest 61,89 and post-test I 64,11. Although there was an improvement of the students' achievement, cycle I was not successful yet because only 6 students $(33.33 \%)$ who passed in post-test I. It means that in the cycle I, the students' achievement was improved enough but it was not successful yet because the indicator of success was not reached yet.

\section{Cycle II}

After analyzing the students' score in the post test of cycle I, the researcher had to conduct the next cycle because the indicator of success was not reached yet. In the cycle II, the researcher gave the treatment then the 
post-test II. After that, the researcher analyzed the result of post-test II and concluded that there were 14 students (77.78\%) who passed the test because they got score $\geq 70$. In post-test II, the lowest score was 58 , the highest score was 76 , and the average score was 69,67.

From the result of the students' score from post-test II, it could be concluded that there was an improvement of the students' score. The improvement could be seen on the average score. The average score in the posttest I and post-test II were 64,11 and 69,67, then the increasing score was 5,86. In the pretest, post-test I, and post-test II, the total students who got score $\geq 70$ were 4,6 and 14 students. Because the achievement of the students had been improved enough and the indicator of success was reached, the research was successful and would not be continued to the next cycle.

Students' Score in Pretest, Post-test Cycle I, and Post-test Cycle II

English learning process was successful in cycle I but the students' average score was low. Meanwhile, the score of the students in post-test I was higher than pretest. Moreover, in cycle II, the students' average score was higher than cycle I.

Based on the result of pretest, posttest I and post-test II, it was showed that there was an improvement of the students' score. It could be seen from the average score from 61,89 to 64,11 became 69,67 . Therefore, the researcher concluded that the research was successful because the indicator of success in this research had been achieved.

\section{The Comparison of Pretest and Post-test}

Based on the explanation of cycle I and cycle II, it could be inferred that the application of Pecha Kucha presentation method could improve the students' speaking performance.
There was a progress average score from $22.22 \%$ to $33.33 \%$ and to $77.78 \%$.

From the graph in figure 4.1, it could be seen that there was an improvement on the average score and total of the students who passed the test from pretest, post-test I to post-test II.

In the graph above, the average score in the pretest was 61,89 and only 4 students or $(22.22 \%)$ passed the test. Moreover, in the post-test I and II there was 6 students or $(33.33 \%)$ who passed the test with the average score of 64,11 and 14 students or (77.78\%) who passed the test with the average score of 69,67 . From the explanation above, the researcher concluded that the research was successful and the cycle could be stopped in the cycle II because the indicator of success $(70 \%$ of students got score $\geq 70$ ) was reached.

\section{The Result of Students' Learning Activities in Cycle I and Cycle II}

The students' learning activities data was gotten from the whole students' learning activities on the observation sheet. The improvement table could be shown as follows:

Table 6

Students' Activities in Cycle I and Cycle II

\begin{tabular}{|c|c|c|c|c|c|c|}
\hline \multirow[t]{2}{*}{ No } & \multirow{2}{*}{$\begin{array}{l}\text { Students' } \\
\text { Activities }\end{array}$} & \multicolumn{2}{|c|}{ Cycle I } & \multicolumn{2}{|c|}{ Cycle II } & \multirow{2}{*}{$\begin{array}{c}\text { Improv } \\
\text { ement }\end{array}$} \\
\hline & & $\mathbf{F}$ & $\%$ & $\mathbf{F}$ & $\%$ & \\
\hline 1 & $\begin{array}{l}\text { The students } \\
\text { attended the class } \\
\text { of English } \\
\text { subject. }\end{array}$ & $\begin{array}{l}1 \\
8\end{array}$ & $100 \%$ & 18 & $100 \%$ & $0 \%$ \\
\hline 2 & $\begin{array}{l}\text { The students } \\
\text { paid attention } \\
\text { while in the } \\
\text { process of } \\
\text { teaching and } \\
\text { learning. }\end{array}$ & $\begin{array}{l}1 \\
4\end{array}$ & $77.78 \%$ & 16 & $88.89 \%$ & $11.11 \%$ \\
\hline 3 & $\begin{array}{l}\text { The students } \\
\text { worked in } \\
\text { group actively. }\end{array}$ & $\begin{array}{l}1 \\
0\end{array}$ & $55.55 \%$ & 15 & $83.33 \%$ & $27.78 \%$ \\
\hline 4 & $\begin{array}{l}\text { The students } \\
\text { were confident } \\
\text { to present their } \\
\text { presentation. }\end{array}$ & 5 & $27.78 \%$ & 14 & $77.78 \%$ & $50 \%$ \\
\hline 5 & $\begin{array}{l}\text { The students } \\
\text { had a good } \\
\text { understanding } \\
\text { in their own } \\
\text { material. }\end{array}$ & 6 & $33.33 \%$ & 13 & $72.22 \%$ & $38,89 \%$ \\
\hline
\end{tabular}


Based on the data above, it could be concluded that the students were active in the learning process because most of the students shown good improvement in their learning activities when Pecha Kucha presentation method was applied in the learning process from cycle I up to cycle II.

\section{CONCLUSION}

Based on the result of the application of Pecha Kucha presentation method in students' speaking performance, it could be concluded that there was an improvement of the students' speaking performance by using Pecha Kucha presentation method among the tenth graders of SMA Muhammadiyah Pekalongan East Lampung. Therefore, the application of Pecha Kucha presentation method could be an effective method to be applied and it could be used as an alternative way in teaching speaking because the method is ease of use and very beneficial one. Moreover, by applying this method, the students also could involve actively in the process of learning. In addition, it made the students easier to understand the material so the students' speaking performance was also improved.

It was supported by the improvement of the students' average score from pretest 61,89 to post-test I 64,11 then became 69,67 in post-test II. In the cycle I, there were 6 students who passed the test. Moreover, in the cycle II, there were 14 students who got score $\geq 70$. It means that the result of cycle II had already reached the indicator of success that was $\geq 70 \%$ of the students who fulfiled the KKM. It was clear enough to state that Pecha Kucha presentation method could be used to improve the students' speaking performance.

\section{SUGGESTION}

Based on the result of the research, the researcher would like to give some suggestion as follows:

1. The students are suggested to be more active in the process of learning English so they can be more competent and well practiced of the material that has been given by the teacher especially in their performance of speaking.

2. The students are suggested to improve their personal competencies of grammar, vocabularies and discourse in order to have a good performance in speaking English.

3. It is suggested for the English teacher to use Pecha Kucha presentation method as an alternative method in the classroom because this method is an effective, simple, and very beneficial to improve the students' speaking performance and to encourage the students in their learning process.

4. The teacher is also expected to give more motivation to the students in order to be more excited in learning English since many students assume that English is very difficult subject to be learned.

5. It is suggested for the headmaster in order to persuade the teachers to use this method because it is very effective method to be applied for the teacher in teaching and delivering the material.

\section{REFERENCES}

Daniel R. Tomal. Action Research for Educators. USA: Scarecrow Press, Inc., 2003.

Donald Ary et.al.. Introduction to Research in Education. Wadsworth: Cengage Learning, 2010. 
Garr Reynolds. Presentation Zen: Simple Ideas on Presentation Design and Delivery (Second Edition). USA: New Riders, 2012.

Gert Rickheit and Hans Strohner. Handbook of Communication Competence. Germany: Mouton de Gruyter, 2008.

Gillian Brown and George Yule. Teaching the Spoken Language. Cambridge: Cambridge University Press, 1999.

H. Douglas Brown. Language Assessment: Principles and Classroom Practices. New York: Pearson Education, 2005.

H. Douglas Brown. Principles of Language Learning and Teaching (4th Edition). New York: Addison Wesley Longman, 2000.

Jeremy Harmer. The Practice of English Language Teaching. London: Longman, 2002.

urse. PASSA Journal, Vol. 47.
Rebecca Hughes. Spoken English, TESOL, and Applied Linguistics: Challenges for Theory and Practice. Great Britain: CPI Antony Rowe, 2006.

Rod Ellis. The Study of Second Language Acquisition. Great Clarendon Street: Oxford University Press, 2003.

William M. Keith and Christian O. Lundberg. Public Speaking: Choices and Responsibility (Second Edition). USA: Cengage Learning, 2014.

O’Malley J. Michael, Pierce V Lorraine, 1996. Authentic Assessment for English Language Learners. Addison Wesley Publishing Comp, Inc.

Floris, Flora Debora. (2014). Idea Sharing: Introducing English As An International Language (Eil) To Pre-Service Teachers In A World Englishes Co 